\title{
Funding innovation in neglected diseases
}

\author{
(c) (1) OPEN ACCESS \\ Concerted action is required to reverse downward trends in research and development
}

\author{
Gavin Yamey professor of global health and public policy ${ }^{1}$, Amie Batson chief strategy officer ${ }^{2}$, \\ Peter H Kilmarx deputy director ${ }^{3}$, Marcel Yotebieng assistant professor ${ }^{4}$
}

${ }^{1}$ Center for Policy Impact in Global Health, Duke University, Durham, NC, USA; ${ }^{2}$ PATH, Seattle, WA, USA; ${ }^{3}$ Fogarty International Center, National Institutes of Health, Bethesda, MD, USA; ${ }^{4}$ Division of Epidemiology, Ohio State University, Columbus, OH, USA

Neglected diseases are those with insufficient markets to attract investment from the drug industry. They primarily affect populations living in low income countries and include malaria, tuberculosis, and diarrhoeal diseases.

Public and philanthropic funding is required to develop new health technologies to control these diseases. While funding from public-private partnerships helped to bring 37 new treatments for neglected diseases to market between 2000 and 2011 , this represented just $4 \%$ of all new therapeutic products registered during this period. As neglected diseases cause about $11 \%$ of the global burden of disease, there is clearly a "persistent insufficiency" in research and development (R\&D). ${ }^{1}$ Except for a one-off injection of funding for Ebola and other African viral haemorrhagic fevers, funding for product development for neglected diseases has shown a downward trend since 2009 . $^{2}$

How can this trend be reversed? Strategies to mobilise funding should engage governments from high, low, and middle income countries, philanthropic foundations, and the private sector. We propose five interconnected approaches.

Firstly, the public and philanthropic sectors should continue to expand successful incentive mechanisms and test new ones to attract industry to participate in product development for neglected diseases. These incentives include long term partnerships that provide public investments in translational research and clinical infrastructure. They also include downstream investments, or "pull" funding (the promise of reward for successful drug development), such as guaranteed purchase of products. ${ }^{3-5}$ Given the growing need for innovative financing, funders should support experimental approaches, such as the Life Prize, which combines upfront grants with pooling of intellectual property into a patent pool. ${ }^{6}$

Secondly, funders could support a "health investors' platform" to improve the targeting of limited resources. Poor coordination of investments is a key challenge in financing research for neglected diseases, especially in the private sector. A health investors' platform would facilitate pooling and sharing of information on R\&D needs, candidate products in the pipeline, estimated development costs and financing gaps, likely markets, and expected health and economic benefits. The platform could help to inform public, private, and philanthropic investors-and attract new investors- to fund those candidate products likely to have the largest public health benefits.

The World Health Organization's new Global Observatory on Health Research and Development, though operating on a shoestring, is a promising first step towards building this kind of platform. ${ }^{7}$ WHO has a critical role in supporting R\&D for neglected diseases, through convening experts, prioritising needs, and supporting countries to conduct health technology assessments. ${ }^{8}$ WHO member states need to increase their financial contributions to fully support this work.

A third approach is for international donors to work more closely with experts within low and middle income countries to tackle the documented mismatch between global and national research priorities. ${ }^{9}$ Developing a new framework for shared prioritisation would be a valuable step towards making $R \& D$ more "needs driven" and the resulting innovations more scalable. Regional institutions in these countries, such as the Africa Centres for Disease Control and Prevention, could help facilitate this coordination.

Fourthly, many low and middle income countries-such as Brazil, Cuba, India, Indonesia, and South Africa-are already funding research into neglected diseases, and a coordinated global effort is needed to encourage others to follow suit. ${ }^{10}$ In 2016, for example, India was the fourth and Brazil was the ninth largest funder of research into neglected disease globally. ${ }^{2}$ Governments and foundations could support the creation of an international "roadmap" for research—an analysis of the current capacities of all countries, the steps each country should take to increase its capacity, and the costs of such improvement. The roadmap would cover the entire life cycle from laboratory to implementation science and include indicators of progress. 
This roadmap could help donors target their support for capacity building in low and middle income countries. It could also be a helpful tool for the new Coalition for African Research and Innovation, an alliance of African science leaders and international funders that aims to build "a highly coordinated, well funded, and African led African innovation enterprise." Other initiatives that could benefit from this roadmap are the Coalition for Epidemic Preparedness Innovations, which aims to develop new vaccines for epidemic control ${ }^{12}$; the G20's collaboration hub for antimicrobial $\mathrm{R} \& \mathrm{D}^{13}$; the European and Developing Countries Clinical Trial Partnership, which has a major focus on building research capacity in $\mathrm{Africa}^{14}$; and the US National Institutes of Health's Fogarty International Center, which builds research capacity in lower income countries. ${ }^{15}$

Finally, donors could help to unlock domestic resources for research in low and middle income countries, such as through a matching fund that pairs global and national resources for shared priorities. The movement towards universal health coverage provides the perfect window of opportunity for these countries' governments to commit a percentage of domestic health budgets to R\&D. Their governments must be in the driving seat in the development of affordable, scalable innovations that will help achieve universal health coverage. Engaging ministries across different sectors and studying the health and economic returns on domestic investment in research could help build political commitment.

Today's health technologies are insufficient to end the death and suffering caused by neglected diseases. Concerted action on multiple fronts is required to mobilise funding to develop new treatments, to optimise its impact, and to put in place a sustainable pipeline of innovations for these important diseases.

Competing interests: We have read and understood BMJ policy on declaration of interests and declare that the Center for Policy Impact in Global Health has received grant funding from Bill \& Melinda Gates Foundation and the Global Health
Technologies Coalition, which have both argued for increased funding for neglected disease R\&D.

Provenance and peer review: Not commissioned, externally peer reviewed.

1 Pedrique B, Strub-Wourgaft N, Some C, etal . The drug and vaccine landscape for neglected diseases (2000-11): a systematic assessment. Lancet Glob Health 2013;1:e371-9. 10.1016/S2214-109X(13)70078-0 25104602

2 Chapman N, Doubell A, Oversteegen L, et al. Neglected disease research and development: reflecting on a decade of global development. G-Finder. $2016 \mathrm{http}: / /$ policycuresresearch.org/downloads/Y10_G-FINDER_full_report.pdf

3 Mueller-Langer F. Neglected infectious diseases: are push and pull incentive mechanisms suitable for promoting drug development research? Health Econ Policy Law 2013;8:185-208. 10.1017/S1744133112000321 23343639

4 Yamey G, Thoumi A, Gonzalez J, et al. Strengthening the United States government's role in product development for global health. Duke University, Policy Cures Research, 2016. At http://centerforpolicyimpact.org/2017/02/24/our-new-report-on-the-role-of-the-us-government-in-supporting-product-development-for-global-health/

5 PATH. Healthier world, safer America: a roadmap for international action to prevent the next pandemic. PATH, 2017.

6 Burki T. Antibiotic development pipeline slows to a trickle. Lancet Infect Dis 2017;17:1128-9. 10.1016/S1473-3099(17)30586-8 29115268

7 Terry RF, Salm JFJr, Nannei C, Dye C. Creating a global observatory for health R\&D. Science 2014;345:1302-4. 10.1126/science.1258737 25214621

8 WHO. Global strategy and plan of action on public health, innovation, and intellectual property. 2011. http://www.who.int/entity/phi/publications/Global_Strategy_Plan_Action. pdf?ua $=1$

9 Viergever RF. The mismatch between the health research and development (R\&D) that is needed and the R\&D that is undertaken: an overview of the problem, the causes, and solutions. Glob Health Action 2013;6:22450.. 10.3402/gha.v6i0.22450 24119660

10 Morel CM, Acharya T, Broun D, etal . Health innovation networks to help developing countries address neglected diseases. Science 2005;309:401-4. 10.1126/science. 111553816020723

11 AESA. Coalition for African Research and Innovation: the need for robust African research and development. 2017. http://aesa.ac.ke/cari/coalition-for-african-research-and-innovation/

12 Cohen C. A half-billion-dollar bid to develop vaccines against the next viral threat. 18 Jan 2017. At http://www.sciencemag.org/news/2017/01/half-billion-dollar-bid-develop-vaccinesagainst-next-viral-threat

13 European Commission. G20 leaders' declaration. shaping an interconnected world. 2017. http://europa.eu/rapid/press-release_STATEMENT-17-1960_en.htm

14 Olliaro P, Smith PG. The European and developing countries clinical trials partnership. $J$ HIV Ther 2004;9:53-6.15534561

15 Breman JG, Bridbord K, Kupfer LE, Glass RI. Global health: the Fogarty International Center, National Institutes of Health: vision and mission, programs, and accomplishments. Infect Dis Clin North Am 2011;25:511-36, vii. 10.1016/j.idc.2011.06.003 21896356

Published by the BMJ Publishing Group Limited. For permission to use (where not already granted under a licence) please go to http://group.bmj.com/group/rights-licensing/ permissionsThis is an Open Access article distributed in accordance with the terms of the Creative Commons Attribution (CC BY 4.0) license, which permits others to distribute, remix, adapt and build upon this work, for commercial use, provided the original work is properly cited. See: http://creativecommons.org/licenses/by/4.0/. 